\begin{tabular}{|c|c|}
\hline & $\begin{array}{c}\text { International Journal of Current Research } \\
\text { and Academic Review }\end{array}$ \\
\hline & $\begin{array}{r}\text { ISSN: 2347-3215 (Online) } \\
\text { Journal homepage: }{ }^{\text {http: } 5: / / w w w ~} \\
\end{array}$ \\
\hline
\end{tabular}

doi: https://doi.org/10.20546/ijcrar.2017.509.006

\title{
Ligation, Transformation and Characterization of Rv 1984c Mycobacterium tuberculosis Indonesian Isolate as an Antigen for Latent TB Immunodiagnostic
}

\author{
$\operatorname{Rosana~Agus}^{1 *}$, Muhammad Nasrum Massi ${ }^{2}$ and Zaraswati Dwyana1 \\ ${ }^{I}$ Department of Biology, Faculty of Life Sciences, Hasanuddin University, Indonesia \\ ${ }^{2}$ Department of Microbiology, Faculty of Medicine, Hasanuddin University, Indonesia \\ *Corresponding author
}

\section{Abstract}

Latent tuberculosis infection (LTBI) is characterised by the presence of immune responses to Mycobacterium tuberculosis infection without clinical evidence of active Tuberculosis (TB). The challenge of identifying LTBI-infected individuals lies in the lack of a diagnostic gold standard for LTBI. Tuberculin skin test (TST) has been used for the diagnosis of tuberculosis for more than a century. Therefore TST has many limitations, so it is extremely urgent to develop a diagnose method to detect LTBI accurately. In this study we used, Culture Fitrate Protein 21 (CFP 21) encoded by the $\mathrm{Rv} 1984 \mathrm{c}$ gene is an immunodominant protein and induces IFN- $\gamma$ from TB patients. The purpose of this study was to ligate, transform and characterize the Rv1984 from M.tuberculosis isolates Indonesia to Escherichia coli JM109. The study was carried out by amplifying the $\mathrm{Rv} 1984 \mathrm{c}$ gene with PCR, ligation to pGEM-T vector and transformation to host cell Eschericia coli JM 109 on LB media induced by X-gal and IPTG. Characterization of pGEM-T-Rv 1984c recombinant clones was performed with PCR and sequencing. The results obtained that the DNA inserts that are ligated to the cloning vector is true Rv $1984 \mathrm{c}$
\end{abstract}

\section{Introduction}

One-third of the world's population is estimated to have LTBI. They do not have active TB disease but may develop it in the near or remote future (WHO, 2015). Studies suggest that active tuberculosis will develop in 5 to $15 \%$ of persons with latent infection during their lifetimes (Getahun et al., 2015).

Identifying persons with LTBI is important to the goal of TB control and elimination because treatment of LTBI can prevent infected persons from developing TB disease and stop the further spread of TB (CDC, 2013). The diagnostic tests used to identify individuals latently

\section{Article Info}

Accepted: 28August 2017

Available Online: 20 September 2017

\section{Keywords}

Culture Fitrate Protein 21,

Rv 1984c,

Ligation,

E. coli JM 109 
TST in low and other middle-income countries (WHO, 2015).

Therefore the specificity of PPD is questionable especially in endemic areas such as Indonesia. Given the limitations of TST tests, current research is directed to find specific antigens that will be used as immunodiagnostics.

CFP-21 is encoded in the RD2 region of M. tuberculosis genome, a region reported to be absent from several strains of BCG. It can elicit a strong skin test reaction, and has been broadly recognised in genetically different strains of inbred mice. CFP-21 is immunologically very active and induces a high interferon- gamma (IFN- $\lambda$ ) release from murine memory effect cells or a pronounced DTH reaction (Wang et al., 2005). CFP-21 is broadly recognised in animals of different major histocompatibility complex class II compositions (Weldingh et al., 1998)

\section{Materials and Methods}

\section{Bacterial Strains and Plasmids}

The cloning vectors pGEM-T Easy (Promega) was used. The strains $M$. tuberculosis was obtained from clinical isolate from Indonesia (Agus, 2016).

\section{Culture Condition}

The E. coli JM 109 were incubate with stirring over night in Luria Bertani (LB) medium in the presence of ampicillin $(1 \mu \mathrm{g} / \mathrm{ml})$ at $37^{\circ} \mathrm{C}$. E.coli JM109 competent cells prepared in advance by the $\mathrm{CaCl} 2$ methods.

\section{PCR}

The following primer was design by (Fu et al., 2009)

Forward 5'-AAGGATCCGATCCGTGTTCGGACA TCGCGGTCG 3'

\section{Reverse 5'-GCTGCCGCCACCGCCGCTTCCGCC ACCGCCGCTTCCACCGCCACCTCCGGCGTGATC GAGCCTGTTCGCC -3'}

The PCR reactions were performed with $1 \mu$ of template in a total volume of $25 \mu \mathrm{l}$. Generally, the PCR profiles consisted of an initial denaturation at $94^{\circ} \mathrm{C}$ for 5 minute, a denaturation at $94^{\circ} \mathrm{C}$ for 1 minute, an annealing at $60^{\circ} \mathrm{C}$ for 1 minute and an extension step at $72^{\circ} \mathrm{C}$ for 45 second. After 30cycles an extension was carried out at $72^{\circ} \mathrm{C}$ for 5 minutes. PCR products were examined by agarose gel electrophoresis and staining with ethidium bromide.

\section{Transformation}

Isolation of DNA and transformation of the E. coli JM 109 cells were performed as described in the guidebook (Sambrook, 2001), with the following modifications. Transformed cells were spread on the appropriate indicator plates containing ampicillin. Colonies were scored for phenotype on Luria Bertani agar plates after 24 hours at $37^{\circ} \mathrm{C}$.

\section{Construction of Recombinant Plasmid of the pGEM- T-Rv 1984c in E. coli JM 109}

Fragment of the Rv 1984c were obtained by PCR using two primers pair and DNA of the M. tuberculosis Indonesian strain as a template. The pGEM-T vector and PCR product were cut with BamHI and HindIII, mixed, and treated with T4 DNA ligase. The result recombinant plasmid pGEM-T-Rv1984c was transformed in E. coli JM 109

\section{Characterization of Recombinant Plasmid of pGEM- T-Rv 1984c}

Isolation of plasmid were performed according to the procedure instructions (BioRad). Characterization was done by PCR analysis and sequensing. PCR analysis was done by using exactly the same cycle as it mentioned before for amplified the Rv 1984c gene

\section{Results and Discussion}

\section{PCR Product and Purification}

The results of PCR amplification of $\mathrm{Rv} 1984 \mathrm{c}$ on $M$. tuberculosis H37RV as positive control and clinical isolates obtained band $608 \mathrm{bp}$. It is appropriate that obtained Fu et al., 2009 that 608 bp band was observed upon staining with ethidium bromide.

\section{Transformation}

The result of the transformation was tested by grown on a solid LB medium with ampicillin, X-GAL and IPTG added. Only E. coli clones containing recombinant clones of pGEM-T-Rv 1984c can grow. White colonies indicate that the insert DNA ( $\mathrm{Rv}$ 1984c) has been 
successfully inserted into the vector and the blue colonies means the DNA insertion is not successfully ligated into the vector.

Bacterial cells are plated on a selective agar medium containing the antibiotic ampicillin and X-gal. If foreign DNA is inserted into the multiple cloning site, then the lac $\mathrm{Z}^{\prime}$ coding region is disrupted and the $\mathrm{N}$-terminal portion of $\beta$-galactosidase is not produced. Since there is no functional $\beta$-galactosidase in the bacteria, the substrate X-gal remains colorless, and the bacterial colony containing recombinant plasmid DNA appears white, thus allowing the direct identification of colonies carrying cloned DNA inserts. If there is no insertion of foreign DNA in the multiple cloning site, then the lac $Z^{\prime}$ gene is intact and enzymatically active $\beta$-galactosidase is produced and X-gal is degraded.

The bacterial colonies containing non-recombinant plasmid DNA thus appear blue (Dubey, 2016).

Fig.1 PCR product of Rv 1984C.

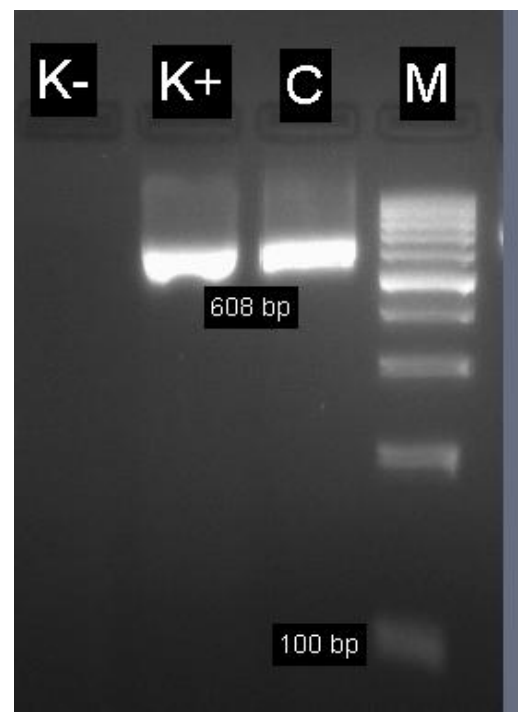

$\mathrm{K}-, \mathrm{K}+, \mathrm{C}, \mathrm{M}=$ Negative control, Positive Control, Sample, Marker

Fig.2 Transformation of Rv 1984c gene to pGEM-T vector $(1$ = white colony, 2 = blue colony

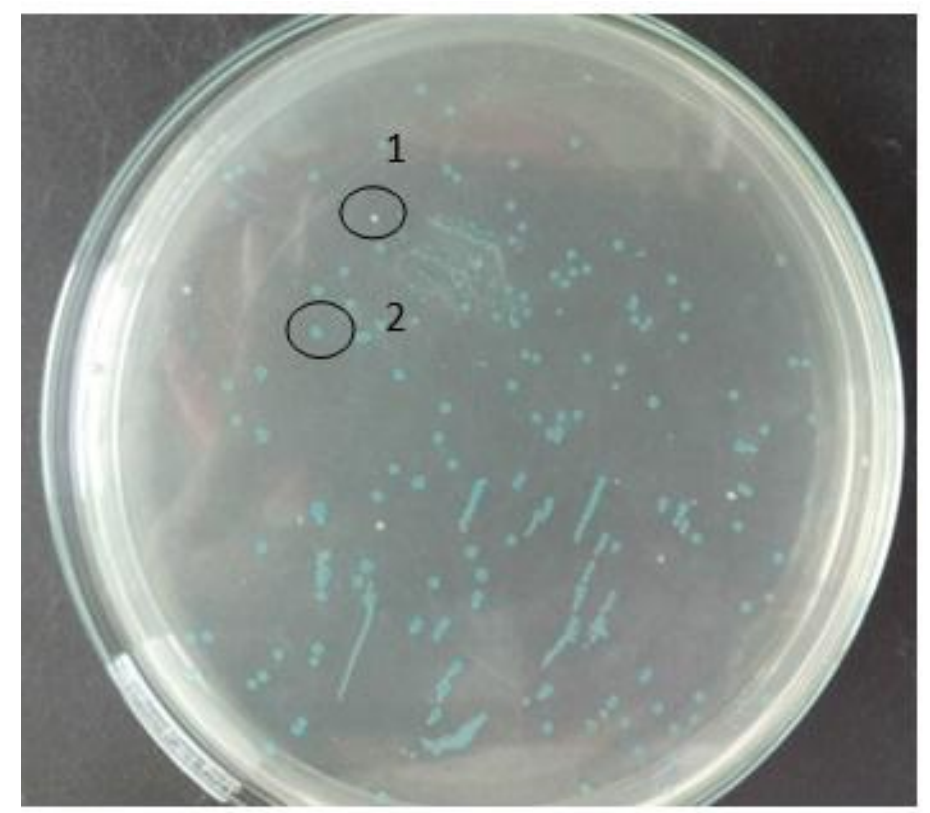


Fig.3 PCR analysis : 1, 2, 3, 4) Rv 1984c, M) Marker 100 bp

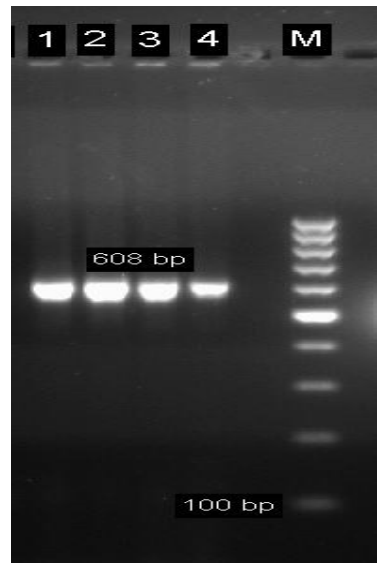

Fig.4 BLAST Analysis of gene Rv 1984c

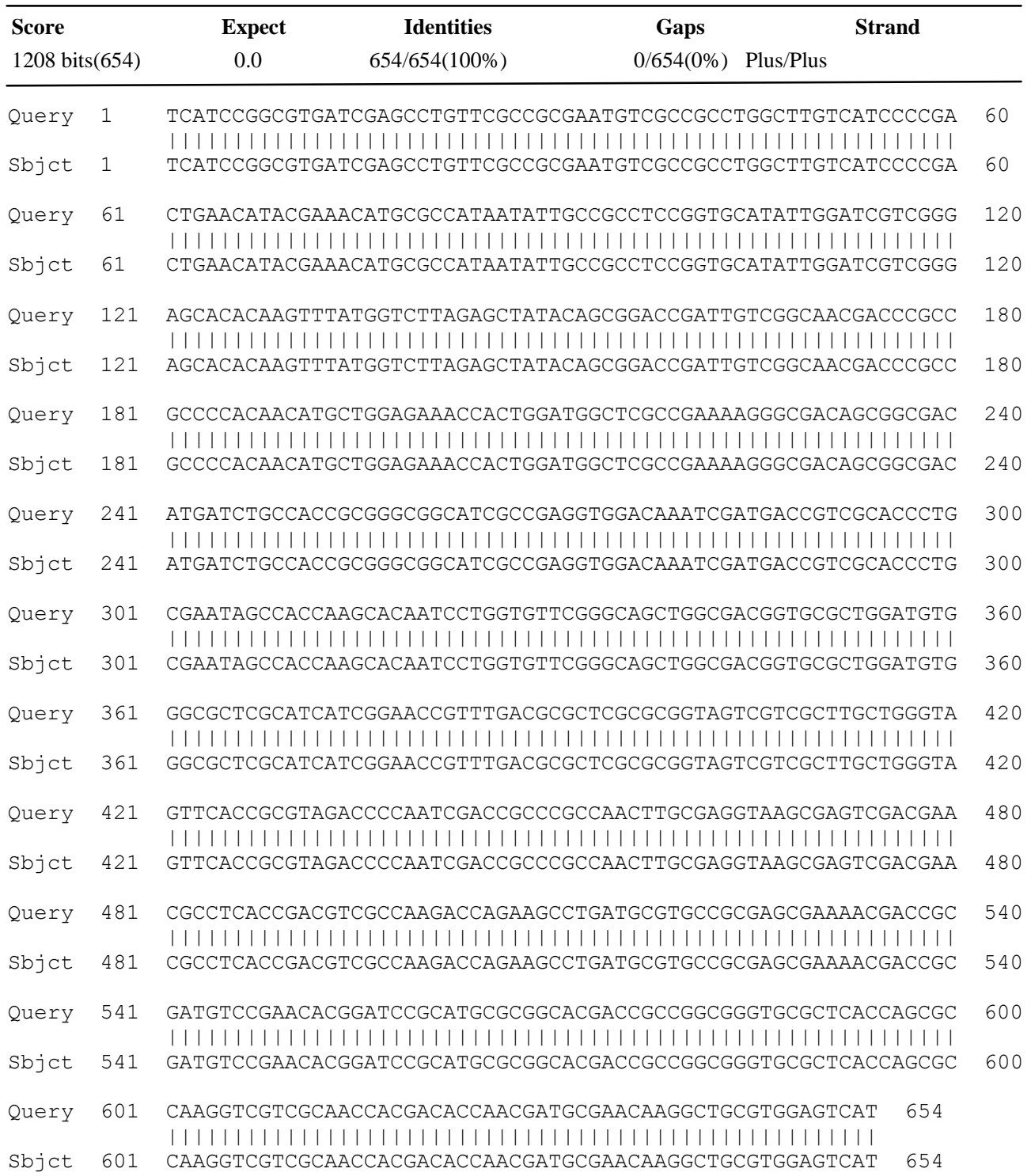


Characterization of Recombinant Plasmid of pGEMT-Rv 1984c

Characterization of recombinant plasmid was done by PCR analysis and sequensing. The plasmid isolation was performed on white colonies and PCR was done by using the same cycle as it mentioned before for amplified the $\mathrm{Rv}$ 1984c gene. Electrophoresis showed that plasmid recombinant contain the Rv 1984c gene as DNA insert was 608 bp (Figure 3)

\section{Sequencing}

Results sequensing of genes $\mathrm{Rv} 1984 \mathrm{c}$ with BLAST results obtained 100\% homology (Figure 4). This suggests that the DNA inserts that are ligated to the pGEM-T vector is true Rv 1984c.

Ligation $\mathrm{Rv} 1984 \mathrm{c}$ to $\mathrm{pGEM}-\mathrm{T}$ vector and transformation to E.coli JM 109 obtained recombinant plasmid pGEMT-Rv1984c. After characterization with PCR and sequencing it was found that the genes had been ligated and transformed were true Rv $1984 \mathrm{c}$

\section{Acknowledgments}

The authors would like to thank Kemenristek Dikti who has funded this research through Hibah Kompetensi 2017

\section{References}

Agus, Rosana, Muhammad Nasrum Massi, Francisca Srioetami Tanoerahardjo, 2016, Cloning Open Reading Frame (ORF) of Rv2430c Mycobacterium tuberculosis Indonesian Isolate in Escherichia coli JM 109, American Journal of Biomedical Research, 2016, Vol. 4, No. 4, 99-101

Centers for Disease Control and Prevention National Center for HIV/AIDS, Viral Hepatitis, STD, and TB Prevention, 2013, Latent Tuberculosis Infection: a guide for primary health care providers, Developed in partnership with Global Tuberculosis Institute at Rutgers, The State University of New Jersey

\section{How to cite this article:}

Rosana Agus, Muhammad Nasrum Massi and Zaraswati Dwyana. 2017. Ligation, Transformation and Characterization of $\mathrm{Rv}$ 1984c Mycobacterium tuberculosis Indonesian Isolate as an Antigen for Latent TB Immunodiagnostic. Int.J.Curr.Res.Aca.Rev. 5(9), 39-43. doi: https://doi.org/10.20546/ijcrar.2017.509.006
Dubey, Vikash Kumar, 2016, Lecture 36: Basics of DNA Cloning-II, NPTEL-II

Getahun H, Alberto Matteelli A, Richard E.Chaisson and Mario Raviglione, 2015, Latent Mycobacterium tuberculosis infection. The New England Journal of Medicine 2015; 372:2127-2135.

Mack U, Migliori GB, Sester M, Rieder HL, Ehlers S, Goletti D, Bossink A, Magdorf K, Hölscher C, Kampmann B, Arend SM, Detjen A, Bothamley G, Zellweger JP, Milburn H, Diel R, Ravn P, Cobelens F, Cardona PJ, Kan B, Solovic I, Duarte R, Cirillo DM, 2009, LTBI: latent tuberculosis infection or lasting immune responses to $\mathrm{M}$. tuberculosis? A TBNET consensus statement. Eur Respir J ; 33: 956-973.

Maine Center for Disease Control and Prevention, 2012, CDC Morbiditiy and Mortality Report: Updated Guidelines for Using Interferon Gamma Release Assays to Detect Mycobacterium tuberculosis Infection-Unites States

Ruiling Fu, Chun Wang, Chunwei Shi, Mengji Lu, Zhengming Fang, Jia Lu,Fang Wang, and Xionglin Fan, 2009, An Improved Whole-Blood Gamma Interferon Assay Based on the CFP21MPT64 Fusion Protein, Clinical and Vaccine Immunology, p. 686-691 Vol. 16, No. 5

Sambrook, J. \& D. W. Russell. 2001. Molecular cloning: A laboratory manual.Volume $1-3.3$ rd ed. Cold Spring Harbor Laboratory Press, New York.

Wang, B.L, Y. Xu, Z-M. Li, Y-M. Xu, X-H. Weng, H-H. Wang, 2005, Antibody response to four secretory proteins from Mycobacterium tuberculosis and their complex antigen in TB patients, Int $J$ Tuberc Lung Dis 9(12):1327-1334

Weldingh K, Rosenkrands I, Jacobsen S, Rasmussen P B, Elhay M J, Andersen P. Two-dimensional electrophoresis for analysis of Mycobacterium tuberculosis culture filtrate and purification and characterization of six novel proteins. Infect Immun 1998; 66: 3492-3500.

World Health Organization. 2015, Guidelines on the Management of Latent Tuberculosis Infection. 